\title{
Green Supply Chain Management and Firm Performance: The Mediating Effect of Green Innovation
}

\author{
Maya Novitasari ${ }^{1,2}$ iD, Dian Agustia ${ }^{3 *}$ iD \\ ${ }^{1}$ Doctoral Program Universitas Airlangga (Indonesia) \\ ${ }^{2}$ Universitas PGRI Madiun (Indonesia) \\ ${ }^{3}$ Universitas Airlangga, Surabaya (Indonesia) \\ maya.novitasari-2019@feb.unair.ac.id, ${ }^{*}$ Correspondingauthor: dian.agustia@feb.unair.ac.id
}

Received: November 2020

Accepted: January 2021

\section{Abstract:}

Purpose: The purpose of this research was to assess green innovation as a mediating variable in the effect of green supply chain management on firm performance.

Design/methodology/approach: This research used the companies listed on the PROPER program for the 2010-2018 period on the Indonesia Stock Exchange. The sample collected by using purposive sampling method obtained 488 companies. The data were tested using STATA 16.

Findings: The results of the analysis showed that green supply chain management had a positive effect on green innovation, green innovation had a positive effect on firm performance, and green supply chain management had no effect on firm performance. Green innovation mediated the relationship between green supply chain management and firm performance.

Research limitations/implications: The limitation of this research was using companies listed on the PROPER program, so it needed to be studied by applying other companies. Besides, it only implemented green innovation, green supply chain management, and firm performance. Future studies can apply other green-related aspects and performances.

Practical implications: Regarding the problem of environmental impact, companies in Indonesia can apply green innovation and green supply chain management to improve their firm performance. Companies in Indonesia are increasingly faced with pressure from stakeholders to implement green supply chain management.

Social implications: It is useful for the Indonesian government in overcoming environmental impact issues by achieving green supply chain management by companies. Companies that achieve green supply chain management will have an impact on increasing green innovation and firm performance.

Originality/value: This research assessed the mediation of green innovation in the effect of green supply chain management on firm performance. This indicated that here there was pressure from stakeholders to pay full attention to the environment, so that companies in Indonesia can apply green innovation and green supply chain management to improve firm performance.

Keywords: green innovation, green supply chain management, firm performance

\section{To cite this article:}

Novitasari, M., \& Agustia, D. (2021). Green supply chain management and firm performance: The mediating effect of green innovation. Journal of Industrial Engineering and Management, 14(2), 391-403. https://doi.org/10.3926/jiem.3384 


\section{Introduction}

Environmental issues emerge along with the development of firm performance and it is a challenge to the business world. As the largest country in Southeast Asia and contributing the highest share of GDP (Gross Domestic Product), manufacturing companies have a major role in the industry in Indonesia, which is $46.5 \%$ of total GDP (Supply Chain Indonesia, 2010; Trading Economics, 2020), causing environmental pollution to increase if not well managed. This is a special concern of the Indonesian government in dealing with environmental impacts, which is stated in environmental economic instruments (Peraturan Pemerintah Republik Indonesia No. 46, 2017). With the pressure from the government, business competition, the community, and investors, companies must pay full attention in supply chain and business development to the environment to provide benefits to the firm performance by implementing green operations, so that green innovation and green supply chain management are considered capable of improving firm performance.

Green innovation is a concept that can reduce negative environmental impacts and improve firm performance to increase public trust, cost efficiency, productivity, and open up new market share opportunities (Agustia, Sawarjuwono \& Dianawati, 2019). Adopting green innovation is not an easy step to take because there are new aspects, among others green process management, green ecosystem reconstruction, and green product R\&D to implement green innovation and it will leave the old work system in terms of organization and employee performance (Ge, Yang, Jiang, Gao, Du \& Zhou, 2018). Green Innovation can be achieved if the company also consider the impact on the environment, such as an unpredictable climate and scarce natural resources. Thus, the company must make changes in its business activities in an innovative way by paying attention to environmental impacts (Khaksar, Abbasnejad, Esmaeili \& Tamošaitienè, 2016). By applying green innovation, it can be useful for changes in firm performance (Ma, Yin, Pan, Cui, Xin \& Rao, 2018) because an improvement in firm performance will be able to create a competitive advantage.

Green supply chain management is an approach that can solve relevant problems, such as: 1) implementation of stakeholders in green practice, 2) motivation of stakeholders to implement GSCM, 3) obstacles faced by stakeholders in implementing GSCM, 4) implications for overall firm performance (Wibowo, Handayani \& Mustikasari, 2018). Supply chain management is a company relationship from suppliers to distribution to consumers, in which the company seeks to participate in preserving the environment in this supply chain. The implementation of GSCM can improve firm performance in terms of profitability and green innovation by developing green products (Abu Seman, Govindan, Mardani, Zakuan, Mat Saman, Hooker et al., 2019). Therefore, the number of companies implementing GSCM to improve their firm performance will increase.

In previous studies, it showed that green supply chain management had an effect on improving firm performance, although green supply chain management requires a large cost (Choi \& Hwang, 2015; Geng, Mansouri \& Aktas, 2017). However, green supply chain management had no significant effect on firm performance because not many company owners or managers had implemented green supply chain management in companies (Khan \& Qianli, 2017; Namagembe, Sridharan \& Ryan, 2016). There was a significant effect of green supply chain management on green innovation, in which when companies implemented green supply chain management, it would increase green innovation (Abu Seman et al., 2019). Companies adopted green supply chain management and green innovation due to pressure from external stakeholders, which is to improve firm performance (Burki, 2018; Seman, Zakuan, Jusoh, Arif \& Saman, 2012). There is a positive influence between green innovation and firm performance, which indicated that technological advances in innovation that took account of environmental impacts would be able to heightens firm performance (Handayani, Wahyudi \& Suharnomo, 2017). Thus, there is an increasing need for green supply chain management, green innovation, and firm performance in companies in Indonesia. The purpose of this research was to assess how companies in Indonesia can improve firm performance through green innovation and green supply chain management. Good firm performance can assist the company to increase production optimally, have adequate human resources, expand market share and increase profits (Abeysekara, Wang \& Kuruppuarachchi, 2019).

This research assessed the direct and indirect effects of green supply chain management, green innovation, and firm performance. This research provided limited knowledge and information on green supply chain management, green innovation, and firm performance, which still have gaps in the results of previous studies, particularly on 
go-public companies in Indonesia. The decision of the company's top management to provide green supply chain management directions to the company is the main driver in improving firm performance (Chu, Yang, Lee \& Park, 2017). However, the green supply chain management investigation is still required consideration because there remains gaps as the objectives of firm performance have different focus (Liu, Feng, Zhu \& Sarkis, 2018). Green supply chain management will be able to increase green innovation to face pressure from external factors (Abu Seman et al., 2019), and this will also improve firm performance. The application of green innovation revealed that this could absorb the concerns of the managerial environment to improve firm performance (Xue, Boadu \& Xie, 2019). With the presence of this gap, this research attempted to answer the following questions: 1) do green supply chain management and green innovation affect firm performance?, 2) does green supply chain management affect green innovation? and 3) can green innovation mediates the effect of green supply chain management on firm performance?

This research also contributed to the company's understanding of improving environmental preservation by implementing green supply chain management and green innovation, which aims to improve firm performance. When facing environmental impacts, the company implements green supply chain management. The implementation of green supply chain management here is how companies obtain materials from suppliers, process them into finished goods, and distribute them to customers by considering environmental concerns. Moreover, the implementation of green innovation in the company's processes in producing products paid great attention to environmental impacts. Green innovation in the company can provide a comprehensive assessment of green supply chain management to improve firm performance (for example, internal environmental management, green purchasing, and customer environmental cooperation). This research will improve company awareness to meet the demands of internal and external factors in response to environmental issues.

\section{Literature Review}

\subsection{Green Supply Chain Management}

Green supply chain management is a supply chain that aims to reduce waste, improve ecosystem quality, eco-efficiency, and material recycling process. In practice, green supply chain management which is in the form of measures in terms of technology, installation of new equipment, providing training for the supplier, and allocating employees is aimed at earning significant profits by paying attention to environmental efficiency (Drohomeretski, Da Costa \& De Lima, 2014; Sugandini, Muafi, Susilowati, Siswanti \& Syafri, 2020). To increase the production of a company and due to the government regulations regarding environmental impacts, it obliges company managers to implement the green supply chain management concept (Khaksar et al., 2016). GSCM has the goal to improve firm performance in terms of economic, environmental, operational, and social performance (Geng et al., 2017).

Green supply chain management can solve problems in various ways, including: implementation of green practice for stakeholders, lack in motivation to implement green supply chain management for stakeholders, obstacles in the problem of implementing green supply chain management for stakeholders, overall performance implications (Wibowo et al., 2018). By implementing green supply chain management, the company can hold or minimize demands from external factors, such as government and consumers or customers (Abu Seman et al., 2019). Green supply chain management can motivate many companies to achieve to maintain and protect the environment for future generations (Sharma, Chandna \& Bhardwaj, 2017).

However, green supply chain management is not only integrated in relation to the process of product manufacture and delivery to customers but must also be considered in the initial stage of product design to the final of product use and waste disposal (Tan, Zailani, Tan \& Shaharudin, 2016). It is very challenging to manage the resources required to implement and apply green supply chain management without the support and commitment from company management (Govindan, Muduli, Devika \& Barve, 2016). In a circular economy, green supply chain management is an effort to optimize resources and as a solution to deal with environmental impacts and supply chains (Kazancoglu, Kazancoglu \& Sagnak, 2018). 


\subsection{Green Innovation}

Green innovation is an advancement in company technology to produce environmentally friendly products, save energy, prevent pollution, recycle waste, and improve environmental management practices that support sustainability. Green innovation is an essential factor for companies in production and resources in taking account to environmental impacts, and this is the fact that shows that the importance of green innovation is the environmental concern which is currently being increased around the world (Khaksar et al., 2016). In implementing green innovation, companies can increase production, maximize internal activities, and reduce operating costs through environmentally friendly innovation (Aguilera-Caracuel \& Ortiz-de-Mandojana, 2013). In its practice, green innovation consists of modifying product designs and processes of production activities from materials, production and delivery which aims to reduce negative impacts on the environment (Chiou, Chan, Lettice \& Chung, 2011).

In dealing with increasing challenges and environmental pressures, company managers must realize that green innovation is a crucial factor in company strategy to achieve a competitive advantage, fulfill market needs, meet stakeholder expectations and sustainable development in improving firm performance (Soewarno, Tjahjadi \& Fithrianti, 2019). Besides, the relationship between green innovation and competitive advantage can be explored by using the RBV (resource-based view) of each company (Nanath \& Pillai, 2017).

Green innovation becomes a force as the main driver in market share and enhancing the company's reputation for carrying out company strategies (Lin, Chen \& Huang, 2014). Companies that implement green innovation will be able to survive and be able to create new opportunities to compete in an increasingly competitive market share and also provide information to stakeholders because, with the green innovation policy, the company has the opportunity to develop and become the main player in the global market (Weng, Chen \& Chen, 2015; Xue et al., 2019).

\subsection{Firm Performance}

Firm performance is a multidimensional concept as it has three indicators, such as production, finance, and marketing that can increase the growth rate of company profits. Due to uncertainty and an increasingly competitive market, companies face a number of risks to establish, maintain, and improve firm performance (Halim, Mustika, Sari, Anugerah \& Mohd-Sanusi, 2017). Firm performance describes the extent to which the company increases production, resource objectives, marketing, and finance (Abeysekara et al., 2019; Tuan, Nhan, Giang \& Ngoc, 2016). There are 3 types of firm performance: multidimensionality, dynamism, and comparability. Multidimensionality is a difference of opinion because there are many stakeholders, differences in strategy, and differences in size in understanding. Dynamism is the goal of senior managers in managing firm performance to earn superior returns for shareholders both in the long and short term. And the last, comparability is the proper benchmarking in analyzing competitor companies in market share (Fei \& Hedley, 2013).

\subsection{Green Supply Chain Management and Green Innovation}

The relationship between green supply chain management and green innovation is the interaction between stakeholders involved in the company's supply chain which can establish green innovation to face the pressure from external factors, such as the government and regulators. Green supply chain management and green innovation in their mechanism have a synergistic relationship, in which there is a significant and positive effect of green supply chain management on green innovation (Abu Seman et al., 2019; Yang, Sun, Zhang \& Wang, 2019). This shows that the company implements green supply chain management as the main driving factor in green innovation. Collaboration between green supply chain management and green innovation will be greatly beneficial for companies in refining product design, product manufacturing processes, and increasing compliance to reduce environmental impacts (Chiou et al., 2011). Companies must strictly monitor and supervise their suppliers in providing environmentally friendly materials and in fulfilling customer demands with environmentally friendly products, so that companies can implement green innovation well. Thus, the researchers proposed the following hypothesis:

\section{H1: Green supply chain management has a positive effect on green innovation}




\subsection{Green Innovation and Firm Performance}

The relationship between green innovation and firm performance is by having green innovation, which is the technology for creating environmentally friendly products that will be able to increase marketing and sales to create a reliable firm performance. Achieving recognition in the market share is the success of the firm performance and a mark of the success of green innovation. (Ma et al., 2018) conveyed that companies that implement green innovation can improve firm performance by: 1) using recycled materials that can reduce costs and increase revenue, and 2) changing environmentally friendly product designs that can increase sales and company profits. Firm performance can be measured financially and non-financially, in which companies that implement green innovation will obtain a "first-mover advantage", including competitive product prices, improved corporate image, broader market share opportunities, and competitive advantages (Weng et al., 2015). Thus, the researchers proposed the following hypothesis:

\section{H2: Green innovation has a positive effect on firm performance}

\subsection{Green Supply Chain Management and Firm Performance}

The implementation of green supply chain management as an effort to preserve the environment can help companies reduce raw material costs and use recycled materials, which will increase more profits and improve firm performance. Geng et al. (2017) suggested that there are five main aspects in green supply chain management and firm performance, including economy, environment, and operations. (Choi \& Hwang, 2015) found out that green supply chain management can be beneficial for firm performance, which is helping companies develop modified environmental management to lead to better firm performance. Green supply chain management has a positive and significant effect on firm performance, which shows that green supply chain management can develop competitive advantage and improve financial performance in the long term (Khan \& Qianli, 2017).

There are differences in company perceptions in implementing green supply chain management to improve firm performance because companies need to comprehend the factors in green supply chain management so that they can be implemented in the company and be sustainable (Kuei, Madu, Chow \& Chen, 2015). Due to this difference in opinion, the researchers proposed the following hypothesis:

\section{H3: Green supphy chain management has a positive effect on firm performance}

\subsection{The Mediating Effect of Green Innovation}

There are some previous studies on the implementation of green supply chain management that affect firm performance. However, in the direct relationship between green supply chain management and firm performance, it is necessary to add another variable as mediation. The mediation variable in this research is green innovation. Green innovation can provide evidence that a company can compete in market share, increase the economy, improve product networks, and improve the socio-technical landscape (Hazarika \& Zhang, 2019). By having green innovation, companies can reduce the environmental impact argued about by external parties to significantly maintain and improve firm performance (Abu Seman et al., 2019). Thus, the researchers proposed the following hypothesis:

\section{H4: Green innovation mediates the effect of green supply chain management on firm performance}

\section{Research Model}

Based on the analysis, this research focused on exploring the mechanisms of green supply chain management, green innovation, and firm performance. The purpose of this research was to assess the direct and indirect relationships of green supply chain management, green innovation, and firm performance. The conceptual framework of this research can be illustrated as follows: 


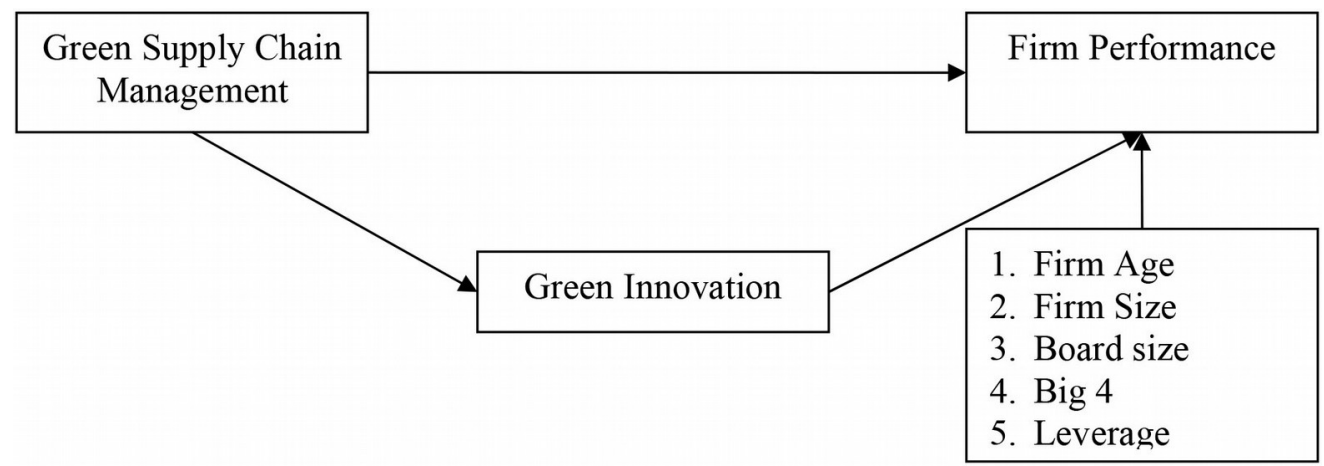

Figure 1. Conceptual research framework

\section{Research Methodology}

\subsection{Research Design}

The population used in this research were companies listed on the PROPER program on the Indonesia Stock Exchange in 2010-2018. The criteria of purposive sampling used were that the company had annual reports and financial statements for 2010-2018. Thus, the sample used was 488 companies. To test variables, it used STATA 16 to examine the direct relationship and the Sobel calculator (www.quantspsy.org) to examine the indirect relationship. There were two regression equations in this research, including:

$$
\begin{gathered}
\mathrm{FP}=\alpha_{1}+\beta_{1} \mathrm{GSCM}+\beta_{2} \mathrm{GI}+\beta_{3} \mathrm{FA}+\beta_{4} \mathrm{FS}+\beta_{5} \mathrm{BS}+\beta_{6} \mathrm{Big} 4+\beta_{7} \mathrm{Lev}+\mathrm{e} \\
\mathrm{GI}=\alpha_{2}+\beta_{8} \mathrm{GSCM}+\mathrm{e}
\end{gathered}
$$

\subsection{Definition Of Operational Variables}

\subsubsection{Dependent Variable}

\subsubsection{Firm Performance}

Firm performance is a reflection of company stakeholders in improving the quality of the company in earning maximum profit to provide information to stakeholders. A good firm performance can increase competitive advantage, market share, loyalty, customer and stakeholder satisfaction. ROA is an indicator to measure how profitable a company is to its total assets, ROA does not always describe the company's earnings strength, but ROA is the most effective, widely available and widely used as a proxy as a measure of firm performance (Issah \& Antwi, 2017; Xu \& Li, 2018). According to Ibhagui and Olokoyo (2018) and Machek (2016), the calculation of firm performance uses ROA which can be formulated as earnings before interest and taxes (EBIT) on total assets.

\subsubsection{Independent Variables:}

\subsubsection{Green Supphy Chain Management}

Green supply chain management is a supply chain management that is integrated with "green" aspects or concerns to environmental impact, starting from the company selecting and purchasing materials from suppliers, product design, product processing, until the product reaching consumers (Srivastava, 2007). Green supply chain management was obtained from an analysis in the company's annual report using indicators and measured in ratios. The indicators used in this analysis were as follows: (1) Had ISO 9000 or ISO 14000 certificates, (2) Green distribution and marketing, (3) Reverse logistics, packaging using recycling, (4) Supplier relationship closeness to determine the purchasing criteria and quality of materials from suppliers and (5) The quality of the product met customer needs (Sharma et al., 2017; Tseng \& Chiu, 2013; Wibowo, 2018).

\subsubsection{Green Innovation}

GI is an implementation and process of new ideas in creating products that can reduce the impact of environmental damage that is related to pollution reduction, energy savings, green product design, waste recycling, and corporate 
environmental management (Agustia et al., 2019). Green innovation was measured from the analysis in the company's annual report using indicators and measured in ratios. The indicators used in this analysis were as follows: (1) The production process used new technology to reduce energy, water, and waste, (2) The product used more non-polluting or hazardous substances (environmentally friendly materials), (3) Used environmentally friendly products and (4) Components or materials in the production process could be recycled or reconditioned (Agustia et al., 2019).

\subsubsection{Control Variables}

This research used the control variables of firm size, firm age, board size, leverage, and KAP big 4. The firm age was measured by the natural logarithm of firm age (Vithessonthi \& Tongurai, 2015). The firm size was measured by the natural logarithm of total assets (Harymawan, 2018). The board size was measured by the number of commissioners in a company (Handriani \& Robiyanto, 2018). The leverage was measured by the ratio of total liabilities to total assets (Vural, Sökmen \& Çetenak, 2012). The KAP big 4 was measured by giving a value of 1 for companies audited by KAP Big 4 and 0 by others (Tanyi \& Smith, 2015).

\section{Discussion Result}

\subsection{Descriptive Statistics}

Table 1 presents descriptive statistics. As presented in Table 1, the minimum and maximum values for green innovation were 0.000 and 1.000 , respectively, those for green supply chain management were 0.000 and 1.000 , and those for firm performance were -0.212 and 0.858 , respectively.

Table 2 presents the Pearson correlation test. The correlation between green supply chain management and green innovation was positive with a significance level at 1\%. The correlation between green innovation and firm performance was positive with a significance value at $1 \%$. Besides, the correlation between green supply chain management and firm performance was positive.

\begin{tabular}{|l|r|r|r|r|r|}
\hline & Mean & Median & Std & Minimum & Maximum \\
\hline FirmPerformance & 0.096 & 0.078 & 0.115 & -0.212 & 0.855 \\
\hline GSCM & 0.548 & 0.600 & 0.207 & 0.000 & 1.000 \\
\hline GI & 0.543 & 0.500 & 0.305 & 0.000 & 1.000 \\
\hline FirmAge & 3.560 & 3.638 & 0.511 & 0.000 & 4.762 \\
\hline FirmSize & 12.854 & 14.560 & 4.318 & 4.151 & 18.335 \\
\hline BoardSize & 8.240 & 5.000 & 15.824 & 2.000 & 11.000 \\
\hline Big4 & 0.461 & 0.000 & 0.499 & 0.000 & 1.000 \\
\hline Leverage & 0.521 & 0.474 & 0.496 & 0.000 & 5.073 \\
\hline
\end{tabular}

Table 1. Descriptive Statistics

\begin{tabular}{|l|r|r|r|r|r|r|r|r|}
\hline & FirmPerformance & GSCM & GI & FirmAge & FirmSize & BoardSize & Big4 & Leverage \\
\hline FirmPerformance & 1.000 & & & & & & \\
\hline GSCM & 0.047 & 1.000 & & & & & & \\
\hline & $(0.301)$ & & & & & & & \\
\hline GI & $0.135^{* * *}$ & $0.478^{* * *}$ & 1.000 & & & & & \\
\hline & $(0.003)$ & $(0.000)$ & & & & & & \\
\hline FirmAge & $0.130^{* * *}$ & 0.036 & $0.121^{* * *}$ & 1.000 & & & & \\
\hline & $(0.004)$ & $(0.426)$ & $(0.008)$ & & & & & \\
\hline FirmSize & $0.305^{* * *}$ & 0.007 & 0.049 & $0.104^{* *}$ & 1.000 & & & \\
\hline
\end{tabular}




\begin{tabular}{|l|r|r|r|r|r|r|r|r|}
\hline & FirmPerformance & GSCM & GI & FirmAge & FirmSize & BoardSize & Big4 & Leverage \\
\hline & $(0.000)$ & $(0.877)$ & $(0.276)$ & $(0.021)$ & & & & \\
\hline BoardSize & $0.105^{* *}$ & 0.037 & 0.041 & -0.013 & 0.027 & 1.000 & & \\
\hline Big4 & $(0.020)$ & $(0.415)$ & $(0.362)$ & $(0.778)$ & $(0.556)$ & & & \\
\hline & $0.125^{* * *}$ & 0.074 & $0.107^{* *}$ & -0.008 & -0.034 & $0.104^{* *}$ & 1.000 & \\
\hline Leverage & $(0.006)$ & $(0.103)$ & $(0.018)$ & $(0.865)$ & $(0.458)$ & $(0.021)$ & & \\
\hline & $-0.150^{* * *}$ & -0.034 & $-0.079^{*}$ & 0.005 & $-0.173^{* * *}$ & -0.033 & -0.050 & 1.000 \\
\hline
\end{tabular}

$*, * *, * * *$ Show significance levels at the 10,5 , and 1 percent levels, respectively.

Table 2. Pearson Correlation

\subsection{Model 1}

Model 1 is shown by simple linear regression to test the effect of green supply chain management on green innovation as seen in Table 3 and Table 5. Based on the t-test results, it obtained the $t$ value for the effect of green supply chain management on green innovation of 11.98 with a significance value of 0.000 (sig $<1 \%$ ), thus indicating that green supply chain management had a positive effect on green innovation, so that H1 was accepted.

\subsection{Model 2}

Model 2 is shown by multiple linear regression to test the effect of green innovation and green supply chain management on firm performance. It also tested the control variables, including firm age firm size, board size, big 4, and leverage on firm performance. The results are presented in Table 3 and Table 5. Based on the results of the t-test, the $t$ value of green innovation on firm performance was 1.98 with a significance value of 0.048 $(\operatorname{sig}<5 \%$ ), thus indicating that green innovation had a positive effect on firm performance, so that $\mathrm{H} 2$ was accepted. The $\mathrm{t}$ value of green supply chain management on firm performance was -0.39 with a significance value of 0.695 ( $\mathrm{sig}>10 \%$ ), thus indicating that green supply chain management had no effect on firm performance, so that $\mathrm{H} 3$ was rejected. In the control variables, the t value for firm age on firm performance was 2.17 with a significance value of 0.031 ( $\mathrm{sig}<5 \%$ ), so that firm age had a positive effect on firm performance. The $t$ value of firm size on firm performance was 6.43 with a significance value of 0.000 ( $\operatorname{sig}<1 \%$ ), so that firm size had a positive effect on firm performance. The $t$ value of board size on firm performance was 1.91 with a significance value of 0.057 ( $\mathrm{sig}<10 \%$ ), so that the board size had a positive effect on firm performance. The $t$ value of Big 4 on firm performance was 2.66 with a significance value of 0.008 (sig $<1 \%$ ), so that big 4 had a positive effect on firm performance. And the $t$ value of leverage on firm performance was -2.04 with a significance value of $0.042(\mathrm{sig}<5 \%$ ), so that leverage had a positive effect on firm performance.

\begin{tabular}{|c|c|c|}
\hline & $\begin{array}{l}(1) \\
\text { GI }\end{array}$ & $\begin{array}{c}(2) \\
\text { FirmPerformance }\end{array}$ \\
\hline \multirow[t]{2}{*}{ GSCM } & $0.706^{* * * k}$ & -0.010 \\
\hline & (11.98) & $(-0.39)$ \\
\hline \multirow[t]{2}{*}{ GI } & & $0.036^{*}$ \\
\hline & & (1.98) \\
\hline \multirow[t]{2}{*}{ FirmAge } & & $0.021 *$ \\
\hline & & (2.17) \\
\hline \multirow[t]{2}{*}{ FirmSize } & & $0.007^{*+2=}$ \\
\hline & & $(6.43)$ \\
\hline BoardSize & & 0.001 \\
\hline
\end{tabular}




\begin{tabular}{|l|r|r|}
\hline & \multicolumn{1}{|c|}{ GI } & \multicolumn{2}{c|}{ FirmPerformance } \\
\hline & & $(1.91)$ \\
\hline Big4 & & $0.026^{* * *}$ \\
\hline & & $(2.66)$ \\
\hline Leverage & $0.156^{* * *}$ & $-0.020^{* *}$ \\
\hline & $(4.52)$ & $(-2.04)$ \\
\hline cons & 0.228 & $-0.093^{* *}$ \\
\hline & 0.226 & $(-2.42)$ \\
\hline r2 & 488 & 0.145 \\
\hline r2_a & & 0.132 \\
\hline N & & 488 \\
\hline ,****** Show significance levels at the 10,5, and 1 percent levels, respectively.
\end{tabular}

Table 3. Regression Results of Green Innovation and Firm Performance

\subsection{The Mediation Effect}

The results of the mediation test using Sobel are presented in Table 4, in which the indirect relationship showed that the $\mathrm{t}$ value was 1.973 with a significance value of $0.048(\mathrm{sig}<5 \%)$. This indicates that green innovation could mediate the relationship between green supply chain management and firm performance, so that $\mathrm{H} 4$ was accepted.

\begin{tabular}{|c|r|r|r|r|}
\hline & Input & Test Statistic & Std. Error & p-value \\
\hline $\mathrm{a}$ & 0.706 & 1.9735815 & 0.01287839 & $0.04843428^{* *}$ \\
\hline $\mathrm{b}$ & 0.036 & & & \\
\hline $\mathrm{Sa}$ & 0.058 & & & \\
\hline $\mathrm{Sb}$ & 0.018 & & & \\
\hline
\end{tabular}

***,*** Show significance levels at the 10, 5, and 1 percent levels, respectively.

Table 4. Mediation Test Results

\begin{tabular}{|l|l|r|r|r|l|}
\hline \multicolumn{2}{|c|}{ Hypothesis } & \multicolumn{1}{|c|}{ Regression coefficient } & \multicolumn{1}{|c|}{ T value } & \multicolumn{1}{|c|}{ P value } & \multicolumn{1}{|c|}{ Description } \\
\hline H1 & GSCM -> GI & 0.706 & 11.98 & 0.000 & Significantly Positive \\
\hline H2 & GI -> FP & 0.036 & 1.98 & 0.048 & Significantly Positive \\
\hline H3 & GSCM -> FP & -0.01 & -0.39 & 0.695 & Not significant \\
\hline H4 & GSCM -> GI -> FP & 0.025 & 1.97 & 0.048 & Significantly Positive \\
\hline
\end{tabular}

Table 5. Hypothesis Test Results

\section{Discussion and Conclusion}

This research tested the direct and indirect relationship. The direct relationship tested the relationship between green innovation and green supply chain management on firm performance. While the indirect relationship tested green innovation as a mediating variable for the relationship between green supply chain management and firm performance. The results of this research were mostly in line with what was hypothesized.

In this research, the first hypothesis showed that companies that implement green supply chain management through the selection of suppliers who were concerned about the environment would be able to increase green innovation. This supported the study by (Abu Seman et al., 2019) which stated that the importance of 
implementing green supply chain management was to increase green innovation in a company. Thus, the decision to purchase raw materials from environmentally friendly suppliers would greatly support the success of green innovation. The second hypothesis showed that there was a relationship between green innovation and firm performance. This was in line with (Zhang, Rong \& Ji, 2019) that the implementation of green innovation could increase sales growth and higher net income so that improved firm performance. Through the implementation of green innovation, companies could withstand the pressure of competitors and could increase sales which would have an impact on firm performance. The third hypothesis showed that there was no relationship between green supply chain management and firm performance. In line with the opinion of (Kirchoff, Tate \& Mollenkopf, 2016), in implementing green supply chain management, companies required a lot of motivation in improving reputation, efficiency, effectiveness, differentiation, and revenue growth.

Besides, this research also showed an indirect effect between green supply chain management and firm performance through the mediation of green innovation. In this regard, green innovation could mediate the relationship between green supply chain management and firm performance. This finding was also confirmed by other researchers, one of them was (Chiou et al., 2011). This assumed that increasing green supply chain management had the potential to increase green innovation and at the same time created better firm performance. Environmental issues led companies to pay more attention to green supply chain management where, in purchasing raw materials from suppliers, they must be environmentally friendly and adopt green innovation to improve firm performance.

The findings of this research are expected to provide essential knowledge to companies listed on the PROPER program in Indonesia as well as practitioners in improving firm performance through green supply chain management and green innovation. Furthermore, this paper broadens the insights on green supply chain management and green innovation in Indonesia as a developing country.

\section{Limitation and Future Research}

There are some limitations to this research. First, this research used companies registered on the PROPER program in Indonesia. The PROPER company is a company rating in environmental management, so that this research testing green supply chain management and green innovation can be biased and subjective. Moreover, the small sample size did not reflect conclusive findings. Further research is expected to use other types of companies such as manufacturing companies or mining companies that have environmental impacts.

Second, this research only examined the firm performance of green supply chain management and firm performance. Further research needs to consider using other variables to analyze firm performance, such as green innovative or green innovation intensity (Aguilera-Caracuel \& Ortiz-de-Mandojana, 2013).

\section{Declaration of Conflicting Interests}

The authors declared no potential conflicts of interest with respect to the research, authorship, and/or publication of this article.

\section{Funding}

The authors received no financial support for the research, authorship, and/or publication of this article.

\section{References}

Abeysekara, N., Wang, H., \& Kuruppuarachchi, D. (2019). Effect of supply-chain resilience on firm performance and competitive advantage: A study of the Sri Lankan apparel industry. Business Process Management Journal, 25(7), 1673-1695. https://doi.org/10.1108/BPMJ-09-2018-0241

Abu Seman, N.A., Govindan, K., Mardani, A., Zakuan, N., Mat Saman, M.Z., Hooker, R.E. et al. (2019). The mediating effect of green innovation on the relationship between green supply chain management and environmental performance. Journal of Cleaner Production, 229, 115-127. https://doi.org/10.1016/j.jclepro.2019.03.211

Aguilera-Caracuel, J., \& Ortiz-de-Mandojana, N. (2013). Green Innovation and Financial Performance: An Institutional Approach. Organization and Environment, 26(4), 365-385. https://doi.org/10.1177/1086026613507931 
Agustia, D., Sawarjuwono, T., \& Dianawati, W. (2019). The mediating effect of environmental management accounting on green innovation - Firm value relationship. International Journal of Energy Economics and Policy, 9(2), 299-306. https://doi.org/10.32479/ijeep.7438

Burki, U. (2018). Green Supply Chain Management, Green innovations, and Green Practices. Understanding Complex Systems, 81-109. https://doi.org/10.1007/978-3-319-94322-0_4

Chiou, T.Y., Chan, H.K., Lettice, F., \& Chung, S.H. (2011). The influence of greening the suppliers and green innovation on environmental performance and competitive advantage in Taiwan. Transportation Research Part E: Logistics and Transportation Review, 47(6), 822-836. https:/ / doi.org/10.1016/j.tre.2011.05.016

Choi, D., \& Hwang, T. (2015). The Impact of Green Supply Chain Management Practices on Firm Performance: The Role of Collaborative Capability. Operations Management Research, 8(3-4), 69-83. https://doi.org/10.1007/s12063015-0100-x

Chu, S.H., Yang, H., Lee, M., \& Park, S. (2017). The impact of institutional pressures on green supply chain management and firm performance: Top management roles and social capital. Sustainability (Switzerland), 9(5). https://doi.org/10.3390/su9050764

Drohomeretski, E., Da Costa, S.G., \& De Lima, E.P. (2014). Green supply chain management: Drivers, barriers and practices within the Brazilian automotive industry. Journal of Manufacturing Technology Management, 25(8), 1105-1134. https://doi.org/10.1108/JMTM-06-2014-0084

Fei, D., \& Hedley, S. (2013). Nature of Firm Performance in Contruction. Journal of Construction Engineering and Management, 140(2), 1-13. https://doi.org/10.1061/(ASCE)CO.1943-7862.0000778

Ge, B., Yang, Y., Jiang, D., Gao, Y., Du, X., \& Zhou, T. (2018). An Empirical Study on Green Innovation Strategy and Sustainable Competitive Advantages: Path and Boundary. Sustainability, 10(10), 1-18. https://doi.org/10.3390/su10103631

Geng, R., Mansouri, S.A., \& Aktas, E. (2017). The Relationship Between Green Supply Chain Management And Performance: A Meta-Analysis of Empirical Evidences in Asian Emerging Economies. International Journal of Production Economics, 183(October 2016), 245-258. https:/ /doi.org/10.1016/j.ijpe.2016.10.008

Govindan, K., Muduli, K., Devika, K., \& Barve, A. (2016). Investigation of the influential strength of factors on adoption of green supply chain management practices: An Indian mining scenario. Resources, Conservation and Recycling, 107, 185-194. https://doi.org/10.1016/j.resconrec.2015.05.022

Halim, E.H., Mustika, G., Sari, R.N., Anugerah, R., \& Mohd-Sanusi, Z. (2017). Corporate governance practices and financial performance: The mediating effect of risk management committee at manufacturing firms. Journal of International Studies, 10(4), 272-289. https:/ / doi.org/10.14254/2071-8330.2017/10-4/21

Handayani, R., Wahyudi, S., \& Suharnomo, S. (2017). The effects of corporate social responsibility on manufacturing industry performance: The mediating role of social collaboration and green innovation. Business: Theory and Practice, 18, 152-159. https://doi.org/10.3846/btp.2017.016

Handriani, E., \& Robiyanto, R. (2018). Institutional ownership, independent board, board size, and firm performance: Evidence from Indonesia. Contaduría y Administración, 64(3), 118. https://doi.org/10.22201/fca.24488410e.2018.1849

Harymawan, I. (2018). Why do firms appoint former military personnel as directors? Evidence of loan interest rate in militarily connected firms in Indonesia. Asian Review of Accounting, 26(1), 2-18. https://doi.org/10.1108/ARA-072016-0086

Hazarika, N., \& Zhang, X. (2019). Evolving theories of eco-innovation: A systematic review. Sustainable Production and Consumption, 19, 64-78. https://doi.org/10.1016/j.spc.2019.03.002

Ibhagui, O.W., \& Olokoyo, F.O. (2018). Leverage and Firm Performance: New Evidence on The Role of Firm Size. North American Journal of Economics and Finance, 45, 57-82. https://doi.org/10.1016/j.najef.2018.02.002

Issah, M., \& Antwi, S. (2017). Role of Macroeconomic Variables on Firms’ Performance: Evidence From The UK. Cogent Economics \& Finance, 67(1), 1-18. https://doi.org/10.1080/23322039.2017.1405581 
Kazancoglu, Y., Kazancoglu, I., \& Sagnak, M. (2018). A new holistic conceptual framework for green supply chain management performance assessment based on circular economy. Journal of Cleaner Production, 195, 1282-1299. https://doi.org/10.1016/j.jclepro.2018.06.015

Khaksar, E., Abbasnejad, T., Esmaeili, A., \& Tamošaitienè, J. (2016). The Effect of Green Supply Chain Management Practices on Environmental Performance and Competitive Advantage: A Case Study of The Cement Industry. Technological and Economic Development of Economy, 22(2), 293-308.

https://doi.org/10.3846/20294913.2015.1065521

Khan, S.A.R., \& Qianli, D. (2017). Impact Of Green Supply Chain Management Practices on Firms' Performance: An Empirical Study From The Perspective of Pakistan. Environmental Science and Pollution Research, 24(20), 16829-16844. https://doi.org/10.1007/s11356-017-9172-5

Kirchoff, J.F., Tate, W.L., \& Mollenkopf, D.A. (2016). The impact of strategic organizational orientations on green supply chain management and firm performance. International Journal of Physical Distribution and Logistics Management, 46(3), 269-292. https:// doi.org/10.1108/IJPDLM-03-2015-0055

Kuei, C.H., Madu, C.N., Chow, W.S., \& Chen, Y. (2015). Determinants and associated performance improvement of green supply chain management in China. Journal of Cleaner Production, 95, 163-173. https://doi.org/10.1016/j.jclepro.2015.02.030

Lin, R.J., Chen, R.H., \& Huang, F.H. (2014). Green innovation in the automobile industry. Industrial Management and Data Systems, 114(6), 886-903. https://doi.org/10.1108/IMDS-11-2013-0482

Liu, J., Feng, Y., Zhu, Q., \& Sarkis, J. (2018). Green supply chain management and the circular economy: Reviewing theory for advancement of both fields. International Journal of Physical Distribution and Logistics Management, 48(8), 794-817. https://doi.org/10.1108/IJPDLM-01-2017-0049

Ma, Y., Yin, Q., Pan, Y., Cui, W., Xin, B., \& Rao, Z. (2018). Green Product Innovation And Firm Performance: Assessing The Moderating Effect Of Novelty-Centered And Efficiency-Centered Business Model Design. Sustainability (Switzerland), 10(6), 1-13. https://doi.org/10.3390/su10061843

Machek, O. (2016). Comparative performance of foreign and domestic family fi rms in Czech Republic. Journal of International Studies, 9(1), 205-218. https://doi.org/10.14254/2071-8330.2016/9-1/15

Namagembe, S., Sridharan, R., \& Ryan, S. (2016). Green Supply Chain Management Practice Adoption in Ugandan SME Manufacturing Firms. World Journal of Science, Technology and Sustainable Development, 13(3), 154-173. https://doi.org/10.1108/WJSTSD-01-2016-0003

Nanath, K., \& Pillai, R.R. (2017). The Influence of Green IS Practices on Competitive Advantage: Mediation Role of Green Innovation Performance. Information Systems Management, 34(1), 3-19. https://doi.org/10.1080/10580530.2017.1254436

Peraturan Pemerintah Republik Indonesia (2017). Instrumen Ekonomi Lingkungan Hidup, 46.

Seman, N.A.A., Zakuan, N., Jusoh, A., Arif, M.S.M., \& Saman, M.Z.M. (2012). The Relationship of Green Supply Chain Management and Green Innovation Concept. Procedia - Social and Behavioral Sciences, 57, 453-457. https://doi.org/10.1016/j.sbspro.2012.09.1211

Sharma, V.K., Chandna, P., \& Bhardwaj, A. (2017). Green supply chain management related performance indicators in agro industry: A review. Journal of Cleaner Production, 141, 1194-1208. https://doi.org/10.1016/j.jclepro.2016.09.103

Soewarno, N., Tjahjadi, B., \& Fithrianti, F. (2019). Green innovation strategy and green innovation: The roles of green organizational identity and environmental organizational legitimacy. Management Decision, 57(11), 3061-3078. https://doi.org/10.1108/MD-05-2018-0563

Srivastava, S.K. (2007). Green supply-chain management: A state-of- the-art literature review. International Journal Of Management Reviews, 9(1), 53-80. https://doi.org/10.1111/j.1468-2370.2007.00202.x

Sugandini, D., Muafi, M., Susilowati, C., Siswanti, Y., \& Syafri, W. (2020). Green Supply Chain Management and Green Marketing Strategy on Green Purchase Intention: SMEs Cases. Journal of Industrial Engineering and Management, 13(1), 79-92. https://doi.org/10.3926/jiem.2795 
Supply Chain Indonesia. (2010). Green Supply Chain Management. https://supplychainindonesia.com/new/wpcontent/files/Potensi GrSCM Turunkan Biaya Logistik Nasional.pdf (Accessed: March 2020).

Tan, C.L., Zailani, S.H.M., Tan, S.C., \& Shaharudin, M.R. (2016). The impact of green supply chain management practices on firm competitiveness. International Journal of Business Innovation and Research, 11(4), 539-558. https://doi.org/10.1504/IJBIR.2016.079507

Tanyi, P.N., \& Smith, D.B. (2015). Busyness, expertise, and financial reporting quality of audit committee chairs and financial experts. Auditing, 34(2), 59-89. https://doi.org/10.2308/ajpt-50929

Trading Economics. (2020). Indonesia GDP Annual Growth Rate2000-2019. https://tradingeconomics.com/indonesia/gdp-growth-annual (Accessed: March 2020).

Tseng, M.L., \& Chiu, A.S.F. (2013). Evaluating firm's green supply chain management in linguistic preferences. Journal of Cleaner Production, 40, 22-31. https://doi.org/10.1016/j.jclepro.2010.08.007

Tuan, N., Nhan, N., Giang, P., \& Ngoc, N. (2016). The effects of innovation on firm performance of supporting industries in Hanoi - Vietnam. Journal of Industrial Engineering and Management, 9(2), 413-431.

https://doi.org/10.3926/jiem.1564

Vithessonthi, C., \& Tongurai, J. (2015). The effect of leverage on performance: Domestically-oriented versus internationally-oriented firms. Research in International Business and Finance, 34, 265-280.

https://doi.org/10.1016/j.ribaf.2015.02.016

Vural, G., Sökmen, A.G., \& Çetenak, E.H. (2012). Affects of working capital management on firm's performance: Evidence from Turkey. International Journal of Economics and Financial Issues, 2(4), 488-495.

Weng, H.H.R., Chen, J.S., \& Chen, P.C. (2015). Effects of green innovation on environmental and corporate performance: A stakeholder perspective. Sustainability (Switzerland), 7(5), 4997-5026. https://doi.org/10.3390/su7054997

Wibowo, M.A. (2018). Faktor Pelaksana Green Supply Chain Management di Industri konstruksi. 11(4), 651-679. https://doi.org/10.3926/jiem.2637

Wibowo, M.A., Handayani, N.U., \& Mustikasari, A. (2018). Factors For Implementing Green Supply Chain Management In The Construction Industry. Journal of Industrial Engineering and Management, 11(4), 651-679. https://doi.org/10.3926/jiem.2637

Xu, J., \& Li, J. (2018). The Impact of Intellectual Capital on SMEs' Performance in China. Journal of Intellectual Capital, 20(4), 488-509. https://doi.org/10.1108/JIC-04-2018-0074

Xue, M., Boadu, F., \& Xie, Y. (2019). The penetration of green innovation on firm performance: Effects of absorptive capacity and managerial environmental concern. Sustainability (Switzerland), 11(9). https://doi.org/10.3390/su11092455

Yang, Z., Sun, J., Zhang, Y., \& Wang, Y. (2019). Perceived fit between green IS and green SCM: Does it matter? Information and Management, 56(7), 103154. https://doi.org/10.1016/j.im.2019.02.009

Zhang, D., Rong, Z., \& Ji, Q. (2019). Resources, Conservation \& Recycling Green innovation and firm performance: Evidence from listed companies in China. Resources, Conservation and Recycling, 144, 48-55. https://doi.org/10.1016/j.resconrec.2019.01.023

Journal of Industrial Engineering and Management, 2021 (www.jiem.org)

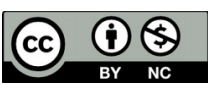

Article's contents are provided on an Attribution-Non Commercial 4.0 Creative commons International License. Readers are allowed to copy, distribute and communicate article's contents, provided the author's and Journal of Industrial Engineering and Management's names are included. It must not be used for commercial purposes. To see the complete license contents, please visit https://creativecommons.org/licenses/by-nc/4.0/. 